\title{
Improve Creative Thinking Ability of Vector Material Through Problem Posing Type Pre Solution Posing at SMAN 3 Semarang
}

\author{
Tri Martini Nurhariyani \\ SMA Negeri 3 Semarang \\ trimartinin@yahoo.com
}

Received: November 2020; Accepted: December 2020; Published: January 2021

\begin{abstract}
In learning process, students often appear reluctant to read mathematics books. So that the students do not understand the meaning and concept of the material they have heard and recorded. This research offers a pre-solution posing type of problem posing model. Students make questions according to the situation given by the teacher and then it solve by themselves or finish them as discussion materials. The research objective is to examine, to describe the increase in creative thinking skills which have the effect of increasing learning achievement through the pre-solution posing type of problem posing model. The research was conducted at X-MIPA 2 SMAN 3 Semarang on vector material. Research variables are creative thinking skills and learning achievement. Data on creative thinking abilities were taken using observation sheets, data on learning achievement were taken by tests. The obtained data were scored, processed and presented descriptively. The results showed, the number of students completed, respectively, on the creative thinking variable was $57 \%$ and $86 \%$, while the learning achievement was $60 \%$ and $91 \%$. The increase that occurs shows the application of improved learning actions on vector material with the pre-solution posing type of problem posing learning model.

Keywords: creative thinking, pre solution posing, learning achievement, problem posing.
\end{abstract}

How to Cite: Nurhariyani, T. M. (2021). Improve Creative Thinking Ability of Vector Material Through Problem Posing Type Pre Solution Posing at SMAN 3 Semarang. Journal of Medives: Journal of Mathematics Education IKIP Veteran Semarang, 5(1), 171-180. 


\section{PENDAHULUAN}

Dalam proses pembelajaran matematika sering kita lihat keengganan siswa untuk membaca buku pelajaran matematika. Hal itu mungkin disebabkan kesulitan mereka memecahkan kata karena kemampuan membaca yang buruk (Toumasis, 2004). Kegiatan membaca dapat meningkatkan kemampuan berpikir kreatif siswa (Segundo Marcos et al., 2020). Berpikir diasumsikan secara umum sebagai proses kognitif yaitu suatu aktivitas mental yang lebih menekankan penalaran untuk memperoleh pengetahuan, Presseinsen (Hartono, 2009). Sedangkan dalam kaitannya dengan berpikir kreatif didefinisikan dengan cara pandang yang berbeda antara lain Jonhson (dalam Siswono, 2004) mengatakan bahwa berpikir kreatif yang mengisyaratkan ketekunan, disiplin pribadi dan perhatian melibatkan aktifitas-aktifitas mental seperti mengajukan pertanyaan, mempertimbangkan informasi-informasi baru dan ide-ide yang tidak biasanya dengan suatu pikiran terbuka, membuat hubungan-hubungan, khususnya antara sesuatu yang serupa, mengaitkan satu dengan yang lainnya dengan bebas, menerapkan imajinasi pada setiap situasi yang membangkitkan ide baru dan berbeda, dan memperhatikan intuisi.

Salah satu strategi pengembangan kemampuan berpikir kreatif relevan dengan ide berpikir kreatif matematik menggunakan model pembelajaran dimana guru dapat memperagakan kreativitasnya dan guru tidak hanya menceramahi siswa tentang kreativitas melainkan guru mendemonstrasikan berpikir kreatif dalam tindakan- tindakannya, memberi peluang bagi para siswa untuk kreatif dengan melibatkan aktifitas mental berupa mengajukan pertanyaan. Dalam hal ini perlu diterapkan model dalam pembelajaran matematika yang dapat melibatkan siswa secara aktif, kreatif dan menyenangkan dengan melibatkan siswa dalam kegiatan diskusi di kelas. Salah satu model pembelajaran yang dapat digunakan yaitu model pembelajaran problem posing tipe pre solution posing.

Problem posing adalah istilah dalam bahasa Inggris yaitu dari kata "problem" artinya masalah, soal, atau persoalan dan kata "pose" yang artinya mengajukan. Problem posing bisa diartikan sebagai pengajuan soal atau pengajuan masalah. Jadi model pembelajaran problem posing adalah suatu model pembelajaran yang mewajibkan para peserta didik untuk mengajukan soal sendiri melalui belajar soal (berlatih soal) secara mandiri (English, 1997) .

Menurut Silver dan Cai (dalam Mahmudi, 2008) pembelajaran problem posing diaplikasikan dalam tiga bentuk aktivitas kognitif matematika, salah satunya adalah pre solution posing yaitu pembuatan soal berdasarkan situasi atau informasi yang diberikan. Problem posing tipe pre solution posing diharapkan mampu meningkatkan kemampuan berpikir kreatif siswa sehingga prestasi belajar matematika pada materi vektor kelas X-MIPA 2 SMA Negeri 3 Semarang juga meningkat

Berdasar latar belakang seperti tersebut di atas, tujuan penelitian ini untuk mengkaji dan mendeskripsikan peningkatan kemampuan berpikir kreatif 
yang berefek pada meningkatnya prestasi belajar siswa melalui model pembelajaran problem posing tipe pre solution posing pada materi vektor. Manfaat yang dapat dipetik dari penelitian ini adalah siswa dapat meningkatkan kemampuan berpikir kreatif sehingga meningkatkan prestasi belajar matematika dan guru mendapatkan referensi baru dan masukan dalam memperluas wawasan dunia pendidikan berkenaan dengan penggunaan model pembelajaran problem posing tipe pre solution posing dalam meningkatkan kemampuan berpikir kreatif.

\section{METODE PENELITIAN}

Subyek yang diteliti ialah siswa yang mendapat pembelajaran vektor pada semester genap yakni peserta didik kelas X-MIPA 2 SMA Negeri 3 Semarang, jumlah responden 35 siswa. Penelitian ini dirancang berlangsung selama 5 bulan. Pada pelaksanaannya dilaksanakan dengan siklus-siklus kegiatan. Hasil siklus sebelumnya digunakan untuk merevisi rancangan pada siklus berikutnya.

Variabel indikator yang diamati dalam penelitian ini meliputi (1) kemampuan berpikir kreatif siswa dan (2) prestasi belajar siswa. Indikator variabel kemampuan berpikir kreatif menurut Guilford (1957) meliputi: kelancaran atau kefasihan (fluency) yaitu memberikan banyak cara atau saran untuk melakukan berbagai hal, berpikir luwes (fleksibel) yaitu dapat melihat suatu msalah dari sudut pandang yang berbeda-beda, keaslian (originality) yaitu memberikan gagasan yang baru dalam menyelesaikan masalah atau jawaban, lain dari yang sudah biasa dalam menjawab suatu pertanyaan, memperinci (elaborasi) yaitu menambahkan atau memperici suatu gagasan sehingga meningkatkan kualitas gagasan tersebut, menilai (evaluation) yaitu dapat menemukan kebenaran suatu pertanyaan atau kebenaran suatu rencana penyelesaian masalah. Pencapaian target keberhasilan untuk variabel berpikir kreatif mencapai skor rata-rata $75 \%$. Indikator untuk variabel prestasi belajar meliputi kemampuan menguasai konsep vektor untuk menyelesaikan masalah yang berhubungan dengan materi vektor. Indikator ketuntasan mencapai skor ratarata $75 \%$.

Penelitian ini dipergunakan untuk mencari suatu strategi pembelajaran yang tepat untuk meningkatkan penguasaan materi vektor secara efektif dan efisien, sehingga arah penelitian ini yaitu mengajak siswa berpikir kreatif dan memberi kefahaman pada siswa dalam penguasaan materi vektor dengan efektif, dan untuk pengukuran masalah tersebut peneliti menggunakan alat pengumpul data yang berupa tes tertulis yang berupa soal dan dilengkapi dengan kisi-kisi soal secara lengkap serta lembar observasi yang dilengkapi dengan rubrik penilaian.

Pada penelitian tindakan kelas ini proses validasi data dilakukan dengan meminta penilaian terhadap teman sejawat yang lebih berpengalaman mengenai isi dan kisi-kisi dari tes tertulis yang digunakan sebagai alat pengumpul data, sehingga alat yang digunakan untuk mengukur kemampuan siswa dalam penelitian ini kevalidannya benar-benar dapat dipertanggungjawabkan. 
Hasil penelitian tindakan kelas ini tercapai sesuai dengan harapan bila dalam penelitian ini: (1) penguasaan materi vektor kelas X-MIPA 2 SMA Negeri 3 Semarang pada akhir penelitian ini meningkat hingga mencapai $75 \%$ peserta didik telah mencapai nilai di atas batas ketuntasan minimal yaitu 75 dan (2) penggunaan model Problem Posing tipe Pre Solution Posing merupakan strategi yang efektif untuk mengajarkan materi vektor, dalam hal ini ditandai dengan peningkatan hasil nilai yang didapatkan masing-masing peserta didik.

Penelitian ini direncanakan dalam dua siklus yang masing-masing silkus terdiri 4 tahap yaitu: perencanaan, implementasi tindakan, observasi dan evaluasi, serta refleksi. Namun jika tujuan belum tercapai, siklus dapat dilanjutkan sampai kriteria keberhasilan PTK ini dicapai. Untuk setiap implementasi tindakan dilakukan pengamatan oleh teman sejawat, khususnya dalam mengamati aktivitas siswa.

Pada tahap perencanaan kegiatan yang dilakukan adalah menyusun rencana pembelajaran yang dilakukan secara kolaboratif dengan teman sejawat, menyiapkan soal-soal berkaitan dengan vektor, menyiapkan alat evaluasi yang berupa tes dan pedoman observasi.

Tahap implementasi tindakan adalah melaksanakan apa yang telah direncanakan pada tahap perencanaan dilaksanakan sesuai dengan jadwal yang disusun. Pelaksana adalah guru matematika kelas X-MIPA 2 dan dalam pelaksanaannya tidak menggangu kegiatan kurikulum di sekolah, karena urutan materi berjalan sesuai dengan program tahunan, program semester dan rencana pembelajaran yang sudah dibuat guru tersebut. Dalam melaksanakan pembelajaran guru meminta teman sejawat, yaitu guru matematika temannya yang sama-sama mengajar di SMA Negeri 3 Semarang untuk melakukan pengamatan terhadap aktivitas siswa menggunakan lembar observasi.

Observasi terhadap kegiatan belajar dilakukan pada saat implementasi tindakan untuk mengetahui jalannya proses pembelajaran dan fokus pengamatan pada aktivitas siswa dalam mengikuti pembelajaran. Menjelang akhir pembelajaran siswa diberi tes. Berdasarkan hasil observasi dan hasil tes, guru bersama teman sejawat melakukan diskusi untuk menilai kelancaran dan kendala dalam pelaksanaan pembelajaran. Evaluasi ini digunakan untuk meningkatkan pelaksanaan pembelajaran berikutnya

Setelah kegiatan pembelajaran pada tahap implementasi dilakukan, peneliti dan teman sejawat melakukan refleksi. Refleksi dilakukan dengan cara menganalisis kegiatan yang sudah dilakukan, sedang dilakukan, dan akan dilakukan. Apabila hasil refleksi belum sesuai dengan kriteria keberhasilan yang telah ditetapkan, maka penelitian diputuskan untuk dilanjutkan pada siklus kedua.

Data kualitatif diambil dengan lembar observasi untuk variabel berpikir kreatif, data kuantitatif diambil dengan tes, dalam hal ini variabel prestasi belajar. Data yang diperoleh diolah dengan menggunakan analisis deskriptif. 


\section{HASIL DAN PEMBAHASAN Hasil Penelitian}

Kegiatan dimulai dengan mengimplementasikan rancangan pembelajaran yang sudah disusun untuk materi pengertian, operasi, dan panjang vektor, yang dilaksanakan 6 jam pelajaran. Pertama dilakukan pembelajaran di kelas, guru menjelaskan materi pengertian, operasi, dan panjang vektor kepada siswa dilanjutkan dengan latihan soal secukupnya. Siswa diberi kesempatan untuk menanyakan penyelesaian soal latihan, guru menjelaskan secara klasikal. Setelah yakin tidak ada pertanyaan lagi dari siswa, maka siswa dikelompokkan secara heterogen, masing-masing kelompok terdiri dari 45 siswa. Masing-masing kelompok diminta mengajukan 2 soal berdasarkan informasi yang diberikan guru, dan kelompok yang bersangkutan harus mampu menyelesaikannya. Kemudian soal-soal tersebut dipecahkan oleh kelompok-kelompok lain. Masingmasing kelompok mempresentasikan soal yang mereka ajukan beserta penyelesaiannya. Untuk memberi penguatan, guru memberikan tugas rumah secara individual. Tugas direview pada tatap muka berikutnya. Guru menampung dan membahas semua permasalahan yang ada. Hasil pengamatan dan tes pada siklus 1 untuk ke dua variabel dapat dilihat pada Tabel 1.

\begin{tabular}{llccc}
\multicolumn{4}{c}{ Tabel 1. Deskripsi Pengukuran Variabel Siklus 1 } \\
\hline No. & Variabel & $\begin{array}{c}\text { Jumlah } \\
\text { Tuntas }\end{array}$ & $\begin{array}{c}\text { Jumlah } \\
\text { Tak } \\
\text { Tuntas }\end{array}$ & Mean \\
\hline 1. & Berpikir & 20 & 15 & $72,57 \%$ \\
& Kreatif & $(57 \%)$ & $(43 \%)$ & \\
2. & Prestasi & 21 & 14 & $74 \%$ \\
& Belajar & $(60 \%)$ & $(40 \%)$ & \\
\hline
\end{tabular}

Dilakukan refleksi, ternyata pada siklus 1 ini masih banyak siswa belum tuntas dan mengalami masalah. Pada variabel berpikir kreatif ternyata masih cukup besar yang belum mengalami ketuntasan $43 \%$. Merupakan bilangan yang cukup tinggi untuk variabel berpikir kreatif. Permasalahan terletak pada siswa kurang mampu memberikan gagasan yang baru dalam menyelesaikan masalah atau jawaban lain dari yang sudah biasa dalam menjawab suatu pertanyaan. Untuk menaikkan berpikir kreatif ini akan dilakukan penyembuhan dengan lebih mendekatkan tugas anak yang berkaitan dengan masalah di sekitar kehidupannya serta dituangkan dalam bentuk LKS seperti yang telah dilakukan oleh Rahayu \& Imran (2017) yang telah mengembangkan LKS untuk meningkatkan ketrampilan berpikir kreatif siswa.

Pada variabel prestasi belajar menjadi rendah, hal ini sebagai dampak kurangnya kemampuan berpikir kreatif siswa dalam pembelajaran. Ada 60\% saja yang mendapatkan skor tuntas. Merupakan tugas cukup serius untuk melaksanakan peningkatan skor variabel di siklus berikutnya.

Dilakukan refleksi, siswa lebih diberi perhatian. Pada tugas siswa diminta tetap mengerjakan walaupun masih banyak kesalahan, siswa dapat menulis pertanyaan sebanyak-banyaknya untuk dibahas dalam review tatap muka.

Pada tahap siklus 2 perencanaan telah dilakukan perbaikan rencana pembelajaran berdasar hasil refleksi siklus 1. Materi yang diberikan adalah perkalian skalar vektor, sudut antara vektor dalam bidang dan ruang, proyeksi 
vektor yang dilaksanakan 8 jam pelajaran. Pada tahap ini untuk pelaksanaannya lebih memperhatikan penyelesaian tugas yang ada pada LKS. Selanjutnya siberi latihan soal. Setelah itu baru siswa dikelompokkan untuk mengajukan soal dan penyelesaian seperti pada siklus 1. Dilakukan pengumpulan tugas rumah, selanjutnya mendiskusikan tentang tugas tersebut. Guru menampung semua permasalahan yang muncul terbaru.

Hasil pengamatan menunjukkan bahwa pada diri siswa nampak adanya perbaikan untuk kedua variabel di atas. Mereka sudah bisa menangkap tugas yang harus dikerjakan, berupaya untuk menganalogi permasalahan yang diberikan dengan konsep dan teori vektor yang bersesuaian. Disini siswa tetap dituntut aktif, bisa bekerja dengan baik dalam menyelesaikan tugas. Hasil pengamatan dan tes siklus 2 pada kedua variabel seperti terlihat pada Tabel 2 .

Tabel 2. Diskripsi Pengukuran Variabel Siklus 2

\begin{tabular}{llccc}
\hline No. & Variabel & $\begin{array}{c}\text { Jumlah } \\
\text { Tuntas }\end{array}$ & $\begin{array}{c}\text { Jumlah } \\
\text { Tak } \\
\text { Tuntas }\end{array}$ & Mean \\
\hline 1. & Berpikir & 30 & 5 & $85,03 \%$ \\
& Kreatif & $(86 \%)$ & $(14 \%)$ & \\
2. & $\begin{array}{l}\text { Prestasi } \\
\text { belajar }\end{array}$ & $\begin{array}{c}32 \\
(91 \%)\end{array}$ & $\begin{array}{c}3 \\
(9 \%)\end{array}$ & $88 \%$ \\
\hline
\end{tabular}

Ternyata pada siklus 2 ini sudah mengalami peningkatan berpikir kreatif dan prestasi belajar. Pada variabel berpikir kreatif ternyata cukup besar mengalami perubahan, yang tuntas mencapai $85,03 \%$, prestasi belajar yang tuntas $88 \%$.

Hasil tersebut menunjukkan peningkatan yang cukup signifikan. Kedua variabel mencerminkan sudah melebihi skor tuntas. Dengan adanya perhatian lebih khusus terhadap tugas rumah yaitu melalui intensifikasi dengan memberikan gambaran pada permasalahan kehidupan sehari-hari serta memotivasi untuk memanfaatkan apa yang sudah dipelajari memberi efektifitas dan kreatifitas baik dari segi waktu maupun dari segi peningkatan skor variabel.

\section{Pembahasan}

Pada pembelajaran dengan strategi di atas yang menjadi fokus pengamatan adalah variabel berpikir kreatif siswa dalam mengikuti pembelajaran dan variabel prestasi belajar di akhir pembelajaran. Rangkuman hasil tiap siklus dapat diperlihatkan seperti pada Gambar 1 dan 2.
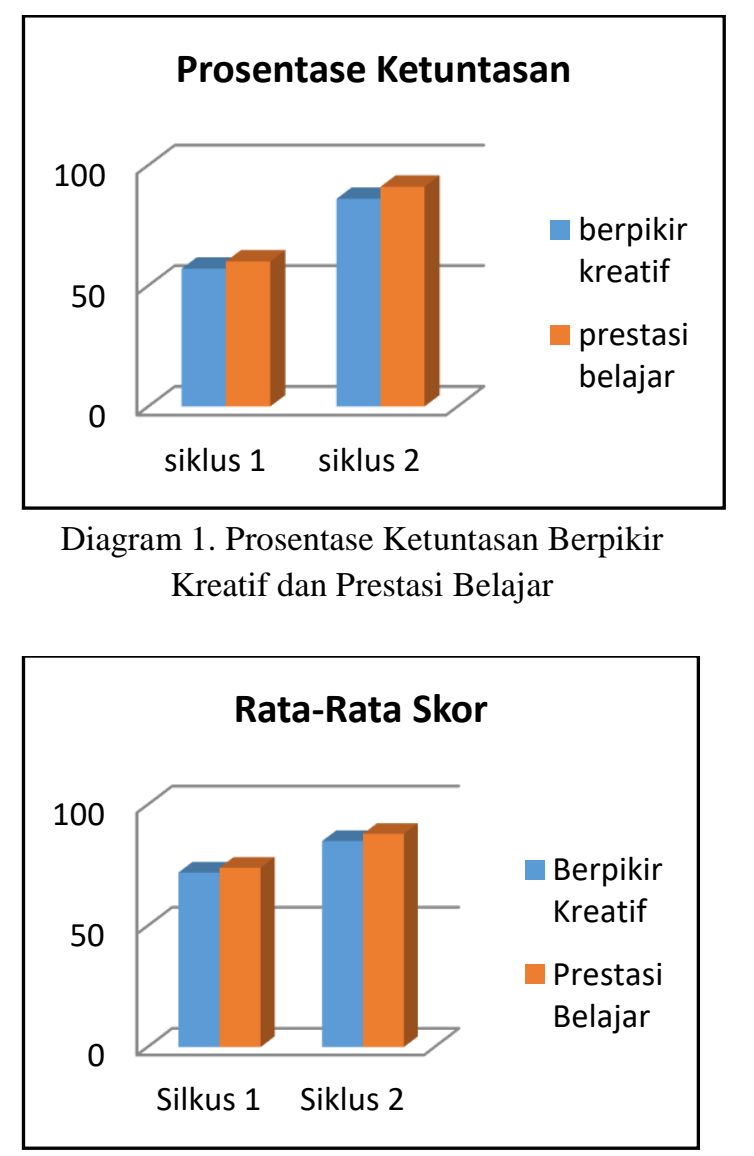

Diagram 2. Rata-rata Skor Berpikir Kreatif dan Prestasi Belajar 
Pada variabel berpikir kreatif, siswa mengalami perubahan setiap siklus cukup signifikan, baik bagi jumlah siswa yang tuntas maupun rata-rata skor siswa. Hal itu terjadi juga pada variabel prestasi belajar.

Penelitian dengan dua siklus ini menerapkan strategi pembelajaran yang mengandalkan pemberian motivasi dengan mengkaitkan materi dengan permasalahan sehari-hari dengan memanfaatkan LKS serta analogi. Tugas bisa diselesaikan di rumah sehingga dapat memberi kesempatan siswa berkomunikasi dengan siapa saja untuk bertanya. Disini siswa benar-benar memerankan fungsinya yakni berperan pada prestasi akademik, berperan pada penyelesaian tugas, berperan secara administrasi. Dengan adanya scafolding dalam pengerjaan LKS serta problem posing (Supianto et al., 2017), sengaja digunakan untuk lebih memberi kemantapan siswa dalam pemahaman konsep sehingga bisa menggunakannya dalam pemecahan masalah.

Hasil pengamatan menunjukkan bahwa mulanya siswa merasa protes dengan tugas yang diberikan, mereka merasa kesulitan menyelesaikan tugas karena sulit dalam membuat soal yang bervariasi serta mempresentasikan penyelesaian soalnya. Akan tetapi memang hal itu yang diinginkan dalam penelitian ini. Siswa termotivasi untuk mempelajari materi vektor, mereka akan berusaha mencari bahan referensi lain, mereka berusaha menganalogikan permasalahan dengan benda di sekitarnya, mereka bisa bertanya pada siapa saja sebelum bertanya pada guru pada saat tatap muka, siswa bisa meningkatkan kemampuan berpikir kreatif. Setelah dilakukan review materi, mereka merasa lega untuk membahas bersama terhadap soal yang diberikan. Pada perjalanan siklus berikutnya yaitu siklus dua siswa sudah bisa merasakan manfaatnya. Hal ini terbukti dengan adanya peningkatan kemampuan berpikir kreatif dan prestasi belajar siswa.

Pada kegiatan mengambil nilai manfaat juga perlu mendapat perhatian. Pada diri siswa pada umumnya mereka belajar matematika yang merupakan konsep abstrak cenderung mempelajari konsepnya sesuai petunjuk guru atau sesuai yang tertulis dalam LKS atau buku sumber. Pada kegiatan ini siswa dilatih untuk bisa memecahkan masalah yang ada dalam LKS yang telah diseting pemberian scaffoldingnya sehingga mereka berusaha mengumpulkan sumber materi untuk menganalogikan permasalahan yang diberikan sehingga tertanam konsep, selanjutnya mengaplikasikan konsep yang dipelajari pada kehidupan sehari-hari. Untuk kegiatan menyemangati diri sendiri tidak banyak terjadi kesulitan. Justru siswa nampak semangatnya untuk menyelesaikan tugas yang diberikan guru.

Kemampuan berpikir kreatif siswa merupakan faktor utama dalam proses belajar dan dengan kemampuan berpikir kreatif yang tinggi maka prestasi belajar siswa akan meningkat.

Hal ini sejalan dengan cara pandang Jonhson (dalam Siswono, 2004) mengatakan bahwa berpikir kreatif yang mengisyaratkan ketekunan, disiplin pribadi dan perhatian melibatkan aktifitasaktifitas mental seperti mengajukan pertanyaan. 
Penelitian ini sejalan dengan penelitian yang telah dilakukan oleh Kojima et al., (2009) yang menyimpulkan bahwa dengan strategi problem posing dalam pembelajaran matematika siswa dapat terlibat langsung dan lebih kreatif dalam proses pemecahan masalah.

Penelitian ini sejalan dengan penelitian yang dilakukan oleh Herawati et al., (2010) yang menyimpulkan bahwa terdapat perbedaan kemampuan pemahaman konsep matematika antara siswa yang memperoleh pembelajaran problem posing dengan yang memperoleh pembelajaran konvensional. Kemampuan pemahaman konsep matematika siswa pada kelas yang memperoleh pembelajaran problem posing lebih baik daripada siswa pada kelas yang memperoleh pembelajaran konvensional.

\section{PENUTUP}

\section{Simpulan}

Materi vektor baik dalam bidang maupun ruang diberikan di SMA untuk membekali siswa dalam membantu mengatasi masalah-masalah yang berhubungan dengan dunia teknik dan ilmu fisika. Agar siswa menguasai konsep yang ada maka perlu adanya usaha bagaimana membelajarkan materi tersebut menjadi menyenangkan dan mudah untuk dipahami. Melalui penelitian, kemudahan tersebut akan mampu diupayakan.

Dengan menerapkan model pembelajaran Problem Posing tipe Pre Solution Posing, siswa akan mengembangkan aktivitasnya dalam kelompok yang heterogen dengan berdiskusi sehingga tercipta transfer ilmu dari interaksi dengan sebaya, dengan keterlibatannya mereka akan mudah melahirkan ide-ide, menciptakan, menghasilkan, menemukan gagasan suatu permasalahan atau persoalan vektor serta sekaligus memberikan ide kreatifnya untuk pemecahan masalah atau soal tersebut.

Hasil yang diperoleh pada siklus 1 dan siklus 2 untuk masing-masing variabel menunjukkan adanya peningkatan. Jumlah siswa yang mencapai skor tuntas $75 \%$ untuk variabel kemampuan berpikir kreatif siswa dalam pembelajaran mengalami peningkatan berturut-turut $57 \%$, dan $86 \%$. Pada variabel prestasi belajar, jumlah siswa yang mencapai tuntas $75 \%$ juga mengalami peningkatan masing-masing berturutan dari $60 \%$ menjadi $91 \%$.

Hasil penelitian yang ditunjukkan oleh skor rata-rata untuk ke dua variabel tersebut di atas juga mengalami peningkatan dari siklus ke siklus. Untuk variabel kemampuan berpikir kreatif berturutan $72,57 \%$ dan $85,03 \%$; untuk variabel prestasi belajar berturutan $74 \%$ dan $88 \%$. Pada siklus ke 2 untuk kedua variabel tersebut semuanya memenuhi mencapai skor ketuntasan yang diprogramkan. Hal ini menandakan bahwa penelitian ini berhasil sesuai dengan tujuan yang dicapai.

\section{Saran}

Dengan meningkatnya skor variabel kemampuan berpikir kreatif dan prestasi belajar siswa pada pembelajaran vektor dengan model pembelajaran Problem Posing tipe Pre Solution Posing maka penelitian ini dikatakan berhasil mencapai peningkatan kemampuan berpikir kreatif yang menyebabkan 
kenaikan prestasi belajar. Oleh karena keberhasilan tersebut maka perlu disarankan hal-hal berikut. (1) Bagi guru hendaknya dalam melakukan pembelajaran selalu berusaha mencari variasi-variasi strategi pembelajaran. Betapa pentingnya membelajarkan matematika dengan memberi motivasi siswa untuk bisa mengajukan permasalahan lengkap dengan solusinya serta menganalogikan permasalahan dengan konsep yang dipelajari. (2) Bagi siswa hendaknya dalam melakukan pembelajaran selalu berusaha aktif dan kreatif. Siswa bersedia belajar mandiri melalui buku-buku bacaan yang mendukung maupun dari sajian pangetahuan yang dapat dicari dengan mudah melalui internet. (3) Bagi penentu kebijakan hendaknya bersifat responsif, memberi fasilitas sarana dan prasarana yang cukup untuk membantu guru kreatif melakukan pembelajaran.

\section{DAFTAR PUSTAKA}

English, L. D. (1997). Promoting a problem-posing classroom. Teaching Children Mathematics, 4(3), 172.

Guilford, J. P. (1957). Creative abilities in the arts. Psychological Review, 64(2), 110-118. https://doi.org/10.1037/h0048280

Hartono. (2009). Perbandingan Peningkatan Kemampuan Berpikir Kreatif dan Aplikasi Matematika Siswa pada Pembelajaran OpenEnded dengan Konvensional di Sekolah Menengah Pertama. UPI.

Herawati, O. D. P., Siroj, R., \& Basir, D. (2010). Pengaruh pembelajaran problem posing terhadap kemampuan pemahaman konsep matematika siswa kelas xi ipa sma negeri 6 palembang. Jurnal Pendidikan Matematika, 4(1).

Kojima, K., Miwa, K., \& Matsui, T. (2009). Study on support of learning from examples in problem posing as a production task. Proceedings of the 17th International Conference on Computers in Education [CDROM]. Hong Kong: AsiaPacific Society for Computers in Education.

Mahmudi, A. (2008). Pembelajaran Problem Posing untuk Meningkatkan Kemampuan Pemecahan Masalah Matematika. Seminar Nasional Matematika Jurusan Matematika FMIPA UNPAD bekerjasama dengan Departemen Matematika UI di Universitas Padjajaran, Bandung.

Rahayu, E., \& Imran, A. (2017). Pengembangan Lembar Kerja Siswa (LKS) Berorientasi Pembelajaran Inkuiri Untuk Meningkatkan Keterampilan Berpikir Kreatif Sisw. Jurnal Ilmiah Mandala Education, 3(1), 403-410.

Segundo Marcos, R. I., López Fernández, V., Daza González, M. T., \& Phillips-Silver, J. (2020). Promoting children's creative thinking through reading and writing in a cooperative learning classroom. Thinking Skills and Creativity, 36, 100663. https://doi.org/10.1016/j.tsc.2020. 100663

Siswono, T. Y. E. (2004). Identifikasi proses berpikir kreatif siswa dalam pengajuan masalah (problem posing) matematika berpandu dengan model wallas dan creative problem solving (CPS). Buletin 
180 | Tri Martini Nurhariyani - Improve Creative Thinking Ability of Vector Material Through Problem Posing ....

Pendidikan Matematika, 6(2), 116.

Supianto, A. A., Hayashi, Y., \& Hirashima, T. (2017). Designing scaffolding system in a problemposing learning environment. 2017 3rd International Conference on Science in Information Technology (ICSITech), 546-551.

Toumasis, C. (2004). Cooperative study teams in mathematics classrooms.

International Journal of

Mathematical Education in

Science and Technology, 35(5), 669-679. 